\title{
STUDI ANALISIS GAYA BELAJAR SISWA YANG MENGACU MODEL GRASHA-REICHMANN PADA MATA PELAJARAN KELOMPOK KEJURUAN KELAS X SMK KOMPETENSI KEAHLIAN TEKNIK GAMBAR BANGUNAN (Penelitian ini dilaksanakan pada SMK Negeri 26 dan 52 Jakarta Semester Genap Tahun 2014/2015)
}

\author{
Suryaman, ${ }^{*}$ Tuti Iriani M.Si, ${ }^{2}$ Santoso Sri Handoyo. ${ }^{3}$ \\ ${ }^{1}$ Alumni Pendidikan Teknik Bangunan, FT UNJ,Jakarta, Indonesia. \\ 2 Pendidikan Teknik Bangunan, FT UNJ, Jakarta, Indonesia. \\ ${ }_{3}^{3}$ Pendidikan Teknik Bangunan, FT UNJ, Jakarta, Indonesia \\ ${ }^{*}$ Corresponding author.
}

\begin{abstract}
This study was aimed to know the representation that refers to students' learning styles of Grasha Model-Reichmann in vocational subjects of 10th Grade of Vocational High School (VHS), Competency of Architecture Engineering. The study lasted from April to May 2015.

This research is using a descriptive quantitative survey approach. The population in this study were all 10th students of 26 and 52 VHS of Jakarta with a total of 122 people. The sampling method is using the saturated sampling techniques with a total of 122 people. The techniques used for data collection are communication techniques and documentation. The instrument for students that are used in the form of a questionnaire from a total of 60 statements refers to GrashaReichmann Student Learning Style (GRSLS). The result is that there are 49 number of valid statement with very high reliability of $(r 11)=$ 0.96 .
\end{abstract}

Based on the research that has been done, the students' learning styles that is mainly used to the Subject of Building Construction is the collaborative learning style (78.93\%), collaborative learning style (80.00\%) for the Measure Soil Science Subjects, collaborative learning style (78.50\%) for the Engineering Mechanics Subject, and participant learning styles (75.66\%) for the Subject of engineering drawings.Results of interviews with teachers indicate that the Subject Building Construction, Measure Soil Science and Engineering Mechanics during the learning process using lecture while teaching style to the Subject engineering drawings using peer tutors. The difference between the student's learning style with teachers teaching style shows the results obtained by each student also had differences.

Keywords: Learning Style, Grasha-Reichmann, and Student 


\section{PENDAHULUAN}

Sekolah merupakan lembaga pendidikan yang didalamnya manusia melakukan kegiatan belajar. Menurut Winkel dalam Purwanto (2011) belajar merupakan proses dalam diri individu yang berinteraksi dengan lingkungan untuk mendapatkan perubahan perilakunya. Belajar adalah aktivitas mental/psikis yang berlangsung dalam interaksi aktif dengan lingkungan yang menghasilkan perubahan-perubahan dalam pengetahuan, keterampilan, dan sikap.

Hasil dari proses belajar akan membawa suatu perubahan pada individu-individu yang sedang belajar. Hamalik (2006) hasil belajar adalah bila seorang telah belajar akan terjadi perubahan tingkah laku pada orang tersebut, misalnya dari tidak tahu menjadi tahu, dan dari tidak mengerti menjadi mengerti.

SMK Kompetensi Keahlian Teknik Gambar Bangunan sebagai salah satu bagian dari Program Keahlian Teknik Bangunan melakukan berbagai usaha dalam meraih lulusan yang memenuhi standar dari dunia usaha ataupun dunia industri, baik dalam melakukan pembelajaran dan juga melalui evaluasi kegiatan belajar mengajar. Pembelajaran di Sekolah Menengah Kejuruan (SMK) dibagi kedalam beberapa kelompok mata pelajaran yaitu mata pelajaran kelompok $A$ dan $B$ yang merupakan kelompok mata pelajaran wajib, dan mata pelajaran kelompok $C$ adalah mata pelajaran kejuruan. Mata pelajaran kejuruan adalah salah satu usaha dalam memenuhi standar dunia usaha ataupun dunia industri, karena dalam mata pelajaran kejuruan berisikan mata pelajaran dasar penunjang yang disesuaikan dengan Dunia Usaha/Dunia Industri (DU/DI).

Menurut www.dikmenjaktim.com SMK Negeri 52 dan 26 adalah dua sekolah yang yang mendapatkan nilai UN teringgi dalam bidang studi keahlian Teknologi dan Rekayasa pada tahun 2014. Namun, dalam salah satu evaluasi pelajaran kejuruan siswa kelas $X$ pada Kompetensi Keahlian Teknik Gambar Bangunan SMK Negeri 52 Jakarta, hasilnya tidak sesuai dengan yang diharapkan. Dengan ketentuan Kriteria Ketuntasan Minimal (KKM) 75 didapatkan hasil:

Tabel 1. Hasil UAS Mata Pelajaran Kejuruan Semester Ganjil

\begin{tabular}{ccccc}
\hline & \multicolumn{4}{c}{ Rentang Nilai } \\
\cline { 2 - 5 } & $\geq 75$ & $74-70$ & $69-60$ & $<60$ \\
\hline Jumlah & 8 orang & 12 orang & 20 orang & 24 orang \\
Persentase & $12,5 \%$ & $18,75 \%$ & $31,25 \%$ & $37,5 \%$ \\
\hline
\end{tabular}

Sumber: SMK Negeri 52 Jakarta, 2014

Berdasarkan Tabel 1, terlihat bahwa hasil belajar pada kelas tersebut bervariasi dalam rentang nilai tertentu. Banyak faktor yang mempengaruhi hasil belajar pada setiap siswa dalam pembelajaran. Menurut Nurman (2006) secara garis besar, faktor yang mempengaruhi hasil belajar dapat dibagi menjadi dua bagian besar yaitu faktor eksternal dan faktor internal.

Faktor eksternal merupakan faktor yang bersumber dari luar individu itu 
sendiri. Faktor eksternal meliputi faktor lingkungan keluarga dan faktor lingkungan sekolah. Faktor lingkungan keluarga yang menentukan hasil belajar seseorang antara lain adanya hubungan harmonis antar anggota keluarga, tersedia tempat dan suasana yang memadai, keadaan ekonomi keluarga yang cukup. Faktor lingkungan sekolah antara lain tegaknya disiplin sekolah, tenaga pengajar yang professional, dan tersedia sarana dan prasarana pendukung belajar.

Faktor internal adalah merupakan faktor yang berasal dari dalam individu itu sendiri. Faktor internal terdiri dari beberapa faktor yakni kondisi fisik yang normal, kondisi kesehatan fisik yang dipengaruhi oleh dua faktor yaknik faktor biologis, dan faktor psikologis (intelegensi, motivasi belajar siswa, daya konsentrasi, minat siswa, dan gaya belajar siswa).

Gaya belajar menurut Gunawan (2003) dalam buku "Genius Learning Strategy)" merangkum ketujuh gaya belajar yaitu berdasarkan pemrosesan informasi (Kagan, Kolb, Honey \& Mumford), kepribadian (Myer-Briggs), modalitas sensori (Blander \& Grinder), lingkungan (Witkin), interaksi (GrashaReichmann), kecerdasan (Gardner), dan wilayah otak (Sperry).

Selain itu, dalam sebuah jurnal World Academy of Science, Engineering, and Technology menjelaskan bahwa:

Tabel 2. Gambaran Skala Untuk Gaya Belajar

\begin{tabular}{cccc}
\hline No. & Gaya Belajar & Tahun & Umur \\
\hline 1 & CITE Learning Style & 1980 & Siswa \\
2 & Grasha-Reichmann Learning Style & 1975 & $\begin{array}{c}\text { Sekolah Menengah dan } \\
\text { Universitas }\end{array}$ \\
& & & $3-12$ tahun \\
3 & Leearning Style Inventory Dunn, Dunn\&Price & 1982 & Anak remaja \\
4 & Learning Style Inventory Kolb & 1976 & $6-12$ tahun \\
5 & Learning Style Profile Keefe & 1986 & $6-12$ tahun \\
6 & Perceptual Learning Style Reid & 1984 & .
\end{tabular}

Sumber: International Journal of Social, Education, Economics, and Management Engineering Vol:4, No. 3, 2010

Tony Grasha (1996) dalam bukunya yang berjudul "Teaching with Style: A Practical Guide to Enhanching Learning by Understanding Teaching and Learning Styles" menjabarkan ciri-ciri/indikator setiap ensi gaya belajarnya, yaitu:

Tabel 3. Dimensi Gaya Belajar Grasha-Reichmann

\begin{tabular}{llll}
\hline No & Dimensi & & \multicolumn{1}{c}{ Karakteristik Pembelajar } \\
\hline & & 1. & Suka berpikir untuk diri mereka sendiri \\
& Mandiri & 2. & Percaya diri dengan kemampuan belajar yang dimiliki \\
& 3. & Menganggap belajar itu penting \\
& 4. & Lebih suka bekerja sendiri \\
\hline \multirow{3}{*}{2 Menggantungkan Diri } & 1. & Rasa ingin tahu rendah \\
& 2. & Belajar hanya apa yang dibutuhkan \\
& 3. & Guru dan teman-teman dianggap sebagai sumber \\
\hline
\end{tabular}




\begin{tabular}{|c|c|c|c|}
\hline & & & belajar \\
\hline & & 4. & Membutuhkan figur otoritas untuk mengatur \\
\hline & & 1. & Mempelajari materi untuk lebih baik daripada yang lain \\
\hline 3 & Rercaing & 2. & Merasa harus bersaing untuk mendapat hadiah (nilai) \\
\hline J & Delsainty & 3. & Ingin menjadi pusat perhatian \\
\hline & & 4. & Menerima pengakuan atas prestasi \\
\hline & & 1. & Belajar dengan bertukar pikiran dan kemampuan \\
\hline 4 & Kerjasama & 2. & Bekerjasama dengan orang lain \\
\hline & & 3. & Suka berdiskusi di dalam kelas \\
\hline & & & Tidak antusias dalam belajar \\
\hline 5 & Tientyenumirivengmina & 2. & Tidak dapat bekerjasama \\
\hline & & 3. & Tidak ingin dikenal dalam kelas \\
\hline & & 1. & Selalu masuk kelas \\
\hline 6 & Partisipasi & & $\begin{array}{l}\text { Mengambil bagian dalam kegiatan pembelajaran } \\
\text { sebanyak mungkin }\end{array}$ \\
\hline & & 3. & Memiliki motivasi untuk belajar \\
\hline
\end{tabular}

Sumber: Tony Grasha, (1996)

Hal ini menjadi menarik untuk diteliti mengenai faktor psikologis yang mempengaruhi hasil belajar karena faktor psikologis salah satu faktor yang termasuk kedalam faktor internal dimana merupakan faktor yang berasal dalam diri siswa yang menunjang proses belajar mengajar.

\section{METODOLOGI PENELITIAN}

Penelitian ini adalah penelitian deskriptif kuantitatif dengan menggunakan metode survey. Populasi dalam penelitian ini adalah seluruh siswa kelas X Kompetensi Keahlian Teknik Gambar Bangunan SMK Negeri 26 Jakarta dan SMK Negeri 52 Jakarta yaitu sebanyak 122 orang. Sampel dalam penelitian menggunakan teknik sampling jenuh yaitu sebanyak 122 orang. Teknik pengumpulan data menggunakan teknik komunikasi dan dokumentasi. Instrumen berupa kuisioner yang mengacu pada Grasha-Reichmann Student Learning Style (GRLSS) untuk siswa dengan jumlah 60 pernyataan dengan langkahlangkah sebagai berikut:

\section{Teknik Komunikasi}

a. Teknik komunikasi langsung dengan melakukan interview/wawancara kepada guru pengampu pada setiap mata pelajaran dengan uraian pada tabel dibawah ini:

Tabel 4. Daftar Nama Guru Untuk Wawancara

\begin{tabular}{cccc}
\hline No & Nama Guru & Mata Pelajaran & Sekolah \\
\hline 1. & M. Joko Prasojo, S. Pd & Konstruksi Bangunan & SMK Negeri 52 \\
2. & M. Joko Prasojo, S.Pd & Ilmu Ukur tanah & Jakarta \\
3. & Agus Helmi M, S.Pd & Mekanika Teknik & SMK Negeri 26 \\
4. & Ikin Sodikin, S.Pd & Gambar Teknik & Jakarta \\
\hline
\end{tabular}


Wawancara dengan guru pengampu pada mata pelajaran yang diteliti bertujuan untuk mengetahui penggunaan metode pembelajaran yang selama ini digunakan dalam pembelajaran sebagai bahan perbandingan dengan gaya belajar yang ditemukan melalui angket/kuisioner. Langkah dalam melakukan wawancara adalah sebagai berikut:

1) Peneliti mengkonsultasikan kepada pembimbing mengenai pertanyaanpertanyaan yang akan diajukan kepada guru pengampu

2) Setelah itu, peneliti menyusun pertanyaanpertanyaan yang telah dikonsultasikan dengan dosen pembimbing

3) Peneliti kemudian melakukan wawancara dengan guru pengampu berdasarkan pertanyaan yang telah dibuat.

b. Teknik komunikasi tidak langsung menggunakan angket/kuisioner yang telah baku yaitu GRLSS (Grasha Reichmann Learning Style Scale) untuk memotret gaya belajar siswa yang mengacu Model Grasha-Reichmann dengan langkah-langkah sebagai berikut:

1) Peneliti menerjemahkan instrumen baku dari Grasha-Reichmann

2) Mengkonsultasikan kepada dosen pembimbing mengenai instrument yang telah diterjemahkan

3) Melakukan uji coba instrumen kepada 10 responden

4) Menghitung validitas dan reliabilitas dari instrumen yang telah dilakukan uji coba dan memilih butir pernyataan mana yang memenuhi persyaratan

5) Selanjutnya melakukan penyebaran instrumen angket/kuisoner kepada siswa kelas $X$ yang telah ditentukan sesuai dengan pembagian mata pelajaran ditiap-tiap sekolah

Tabel 6. Sampel Penelitian

\begin{tabular}{ccc}
\hline Mata Pelajaran & Sekolah & Jumlah Sampel \\
\hline $\begin{array}{c}\text { Konstruksi Bangunan } \\
\text { Ukur Tanah }\end{array}$ & $\begin{array}{c}\text { SMK Negeri 52 } \\
\text { Jakarta }\end{array}$ & 58 orang \\
\hline $\begin{array}{c}\text { Menggambar Teknik } \\
\text { Mekanika Teknik }\end{array}$ & $\begin{array}{c}\text { SMK Negeri 26 } \\
\text { Jakarta }\end{array}$ & 64 orang \\
\hline
\end{tabular}

6) Penyebaran angket/kuisoner pada setiap mata pelajaran diberikan jeda 1 minggu dikarenakan pertimbangan untuk memperoleh hasil yang cukup berbeda dan menghindari kejenuhan 
responden untuk mengisi angket/kuisioner tersebut.

7) Penyebaran angket/kuisoner kepada responden dilakukan setelah selesai proses pembelajaran yaitu:

Tabel 7. Penyebaran Kuisioner Gaya Belajar

\begin{tabular}{cl}
\hline Mata Pelajaran & \multicolumn{1}{c}{ Materi Pokok } \\
\hline Konstruksi Bangunan & Menalar spesifikasi dan karakteristik bahan \\
& kayu \\
Ilmu Ukur Tanah & $\begin{array}{l}\text { Survey dan pemetaan keliling lingkaran } \\
\text { dengan alat theodolite }\end{array}$ \\
& Menghitung dan menggambar bidang M dan \\
Mekanika Teknik & D \\
Gambar Teknik & Software AutoCAD \\
\hline
\end{tabular}

2. Teknik Dokumentasi

Teknik ini digunakan untuk mengumpulkan literature yang akan menunjang dalam penelitian. Selain itu juga untuk mendapatkan data mengenai hasil belajar UAS pada semester genap Tahun 2014/2015 pada setiap mata pelajaran.

\section{HASIL PENELITIAN DAN PEMBAHASAN}

\section{Hasil Penelitian}

1. Konstruksi Bangunan

Gambaran siswa mengenai gaya belajar pada Mata Pelajaran Konstruksi Bangunan terlihat pada Tabel 4.8 berikut ini:

Tabel 8. Persentase (\%) Jawaban Responden Pada Mata Pelajaran Konstruksi Bangunan

\begin{tabular}{ccc}
\hline No. & Gaya Belajar & Persentase Total \\
\hline 1 & Competitive & $75.17 \%$ \\
2 & Collaborrative & $78.93 \%$ \\
3 & Avoidant & $66.55 \%$ \\
4 & Participant & $76.93 \%$ \\
5 & Dependent & $76.70 \%$ \\
6 & Independent & $74.73 \%$ \\
\hline
\end{tabular}

Berdasarkan Persentase Jawaban Responden Pada Mata Pelajaran Konstruksi Bangunan pada Tabel 4.8 menunjukan bahwa gaya belajar collaborative lebih dominan (78.93\%) dibandingkan dengan gaya belajar avoidant $(66.55 \%)$ yang yang kurang diterapkan oleh siswa pada Mata Pelajaran Konstruksi Bangunan

2. IImu Ukur Tanah 
Secara keseluruhan, gambaran

responden terlihat sebagai berikut ini:

gaya belajar siswa yang dijawab oleh

Tabel 9. Persentase (\%) Jawaban Responden Pada Mata Pelajaran IImu Ukur Tanah

\begin{tabular}{ccc}
\hline No. & Gaya Belajar & $\%$ Total \\
\hline 1 & Competitive & $76.38 \%$ \\
2 & Collaborrative & $80.00 \%$ \\
3 & Avoidant & $67.87 \%$ \\
4 & Participant & $76.90 \%$ \\
5 & Dependent & $76.02 \%$ \\
6 & Independent & $74.09 \%$ \\
\hline
\end{tabular}

Berdasarkan hasil penyebaran kuisioner kepada responden pada Mata Pelajaran IImu Ukur Tanah menunjukkan sebagaian besar responden cenderung didominasi dengan menggunakan gaya belajar collaborative $(80,00 \%)$. Sedangkan gaya belajar yang kurang digunakan adalah gaya belajar avoidant $(67,87 \%)$.

3. Mekanika Teknik

Berdasarkan jawaban dari keseluruhan responden mengenai gaya belajar siswa pada Mata Pelajaran Mekanika Teknik menunjukkan sebagai berikut:

\section{Tabel 10. Persentase (\%) Jawaban Responden Pada Mata Pelajaran Mekanika Teknik}

\begin{tabular}{ccc}
\hline No. & Gaya Belajar & $\%$ Total \\
\hline 1 & Competitive & $74.14 \%$ \\
2 & Collaborrative & $78.50 \%$ \\
3 & Avoidant & $67.60 \%$ \\
4 & Participant & $74.76 \%$ \\
5 & Dependent & $74.86 \%$ \\
6 & Independent & $73.08 \%$ \\
\hline
\end{tabular}

Berdasarkan Tabel 10, hal ini persentase total jawaban yang diberikan oleh responden terhadap kuisioner gaya belajar siswa pada Mata Pelajaran Mekanika Teknik. Gaya belajar collaborative lebih mendominasi $(78,50 \%)$ dibandingkan dengan yang lainya. Sementara gaya belajar avoidant adalah gaya belajar yang kurang diminati oleh responden (67.60\%).

4. Gambar Teknik

Berdasarkan hasil jawaban dari responden yang diberikan pada Mata Pelajaran Gambar Teknik dapat dijelaskan pada tabel berikut ini: 
Tabel 11. Persentase (\%) Jawaban Responden Pada Mata Pelajaran Gambar Teknik

\begin{tabular}{ccc}
\hline No. & Gaya Belajar & $\%$ Total \\
\hline 1 & Competitive & $73.55 \%$ \\
2 & Collaborrative & $74.78 \%$ \\
3 & Avoidant & $66.20 \%$ \\
4 & Participant & $75.66 \%$ \\
5 & Dependent & $72.64 \%$ \\
6 & Independent & $74.20 \%$ \\
\hline
\end{tabular}

Berdasarkan Tabel 4.30, hasil jawaban responden mengenai gaya belajar pada Mata Pelajaran Gambar Teknik menunjukkan bahwa $75,66 \%$ dari keseluruhan responden mendominasi gaya belajar participant dibandingkan dengan gaya belajar avoidant yang kurang diminati oleh responden $66,20 \%$.

\section{Pembahasan}

Hasil penelitian mengenai gaya belajar siswa yang mengacu Model Grasha-Reichmann pada mata pelajaran kelompok kejuruan pada kelas $X$ SMK Kompetensi Keahlian Teknik Gambar Bangunan menunjukkan bahwa:

Tabel 12. Kesimpulan Gaya Belajar Pada Masing-masing Mata Pelajaran

\begin{tabular}{|c|c|c|c|c|c|c|}
\hline MP & $\begin{array}{c}\text { Competitiv } \\
e\end{array}$ & $\begin{array}{c}\text { Collaborativ } \\
e\end{array}$ & $\begin{array}{c}\text { Avoidan } \\
t\end{array}$ & $\begin{array}{c}\text { Participa } \\
n t\end{array}$ & $\begin{array}{c}\text { Depende } \\
n t\end{array}$ & $\begin{array}{c}\text { Independe } \\
n t\end{array}$ \\
\hline $\begin{array}{c}\text { Konstruksi } \\
\text { Bangunan }\end{array}$ & & & & & & \\
\hline Imu Ukur Tanah & & & & & & \\
\hline Mekanika Teknik & & & & & & \\
\hline Gambar Teknik & & & & & & \\
\hline
\end{tabular}

Menurut Panitz (2005) dalam Suratno (2013) dalam pembelajaran collaborative dapat mengembangkan nilai-nilai kebersamaan bekerja dalam tim, antara lain mampu "berbagi" baik pekerjaan maupun tanggungjawab, mampu "bekerjasama" dalam penyelesaian tugas atau pekerjaan, mampu "memperhatikan hak dan kesejahteraan orang lain" dan "peduli terhadap orang lain" atau berempati. Sejalan dengan hal tersebut, berdasarkan survey National Assosiation of Colleges and Employers USA (2002) terhadap 457 pimpinan perusahaan menjelaskan bahwa nilai bukanlah hal yang dianggap penting dalam dunia kerja, yang jauh lebih penting adalah softskill dimana salah satu kemampuan yang diperlukan adalah kemampuan dalam bekerjasama.

Sedangkan Mata Pelajaran Gambar Teknik, pada Tabel 4.36 menunjukkan kecenderungan siswa lebih mengarah pada gaya belajar participant. Mata Pelajaran Gambar Teknik siswa lebih 
banyak diberikan tugas menggambar. Selain itu, dalam mata pelajaran tersbut juga mempelajari peralatan dalam menggambar, bentuk dan fungsi garis, aturan kelengkapan inormasi, dan gambar proyeksi. Dengan hal tersebut, siswa harus mengambil bagian sebanyak-banyaknya dan siswa harus lebih aktif dalam pembelajaran untuk dapat memahami Mata Pelajaran Gambar Teknik.

Menurut pendapat Made Sumadi dalam Pawit (2011) proses keterlibatan siswa dalam pembelajaran partisipasi akan memungkinkan terjadinya asimilasi dan akomodasi kognitif dalam pencapaian pengetahuan, perbuatan serta pengalaman langsung terhadap balikannya dan pembentukan nilai dan sikap. Burt, dkk dalam Suryosubroto (2002) juga berpendapat bahwa dengan partisipasi memliki banyak manfaat mengenai komunikasi dua arah dan memberikan sumbangan yang berarti positif.

Hasil wawancara dari dengan guru pengampu pada setiap mata pelajaran mengatakan bahwa untuk Mata Pelajaran Konstruksi Bangunan dan Mekanika Teknik guru menyampaikan materi secara langsung kepada siswa atau

Tabel 13. Persentase Hasil Belajar Pada Masing-Masing Mata Pelajaran Berdasarkan Metode Selama Pembelajaran

\begin{tabular}{cccccc}
\hline Mata Pelajaran & Gaya Belajar & $\begin{array}{c}\text { Gaya } \\
\text { Mengajar }\end{array}$ & KKM & $\geq$ KKM & $<$ KKM \\
\hline Konstruksi Bangunan & Collaborative & Ceramah & 80 & $\begin{array}{c}23 \text { siswa } \\
(45.31 \%)\end{array}$ & $\begin{array}{c}35 \text { siswa } \\
(54.69 \%)\end{array}$ \\
\hline IImu Ukur Tanah & Collaborative & Ceramah & 75 & $\begin{array}{c}32 \text { siswa } \\
(55.17 \%)\end{array}$ & $\begin{array}{c}26 \text { siswa } \\
(44.83 \%)\end{array}$ \\
\hline Mekanika Teknik & Collaborative & Ceramah & 75 & $\begin{array}{c}36 \text { siswa } \\
(56.25 \%)\end{array}$ & $\begin{array}{c}28 \text { siswa } \\
(43.75 \%)\end{array}$ \\
\hline Gambar Teknik & Participant & $\begin{array}{c}\text { Tutor } \\
\text { Sebaya }\end{array}$ & \multirow{2}{*}{80} & $\begin{array}{c}56 \text { siswa } \\
(87.5 \%)\end{array}$ & $\begin{array}{c}8 \text { siswa } \\
(12.5 \%)\end{array}$ \\
\hline
\end{tabular}

dengan kata lain guru tersebut sebagian besar pembelajarannya masih menggunakan metode ceramah/konvensional saat proses pembelajaran. Pada Mata Pelajaran IImu Ukur Tanah, guru pengampu mata pelajaran menggunakan dua metode yaitu metode ceramah dan metode proyek. Metode proyek pada IImu Ukur Tanah digunakan hanya pada saat melakukan praktek survey dan pemetaan dengan menggunakan alat leveling. Sementara itu, untuk Mata Pelajaran Gambar Teknik menggunakan metode tutor sebaya. Metode tutor sebaya dalam Gambar Teknik dilakukan agar siswa berusaha lebih aktif mencari hal-hal yang berkaitan dengan materi pada Gambar Teknik tersebut kepada teman/rekan yang telah memiliki pengalaman tersebut. Dengan demikian, kemampuan siswa pada Mata Pelajaran Gambar Teknik tergantung pada kemampuan masingmasing siswa untuk bertanya kepada rekan/teman sebayanya.

Hasil belajar siswa pada masingmasing mata pelajaran dengan menggunakan metode pembelajaran yang selama ini digunakan dapat terlihat pada 
Tabel 13 menunjukkan bahwa pada Mata Pelajaran Konstruksi Bangunan, IImu Ukur Tanah dan Mekanika Teknik selama proses pembelajaran yang telah berlangsung selama ini guru pengampu pada setiap mata pelajaran lebih menggunakan gaya mengajar secara ceramah, sedangkan gambaran gaya belajar siswa pada masing-masing mata pelajaran adalah gaya belajar collaborative/kerjasama. Hal ini menyebabkan bahwa dengan penggunaan gaya mengajar yang selama ini digunakan, banyak siswa yang memiliki hasil belajar dibawah KKM.

Untuk Mata Pelajaran Gambar Teknik, dari Tabel 4.32 menunjukkan bahwa guru pengampu mata pelajaran selama proses pembelajaran menggunakan metode tutor sebaya, sedangkan gaya belajar siswa pada mata pelajaran ini adalah participant/partisipasi. Gaya belajar participant ini sesuai dengan metode tutor sebaya dimana siswa lebih aktif dalam proses pembelajaran dan kemampuan yang dimiliki oleh siswa bergantung pada tanggungjawab masingmasing untuk dapat menyerap pelajaran yang disampaikan. Hal ini dibuktikan dengan hasil belajar yang diperoleh siswa, sebagian besar siswa mendapatkan nilai yang berada diatas KKM. Metode tutor sebaya yang membuat siswa lebih aktif dalam pembelajaran sesuai dengan ciri/karakteristik gaya belajar participant yang dikemukakan oleh Grasha dan Sherly Hruska-Reichmann (1974) dalam Ghufron (2012) yaitu bertanggungjawab, berpartisipasi aktif dan harus ambil bagian sebanyak-banyaknya dalam setiap kegiatan yang ada hubungannya dengan pelajaran.

Kajian dari Martia Fahrianti (2012) juga mengatakan bahwa terdapat perbedaan hasil belajar pembelajaran dengan berdasarkan gaya belajar yang lebih tinggi dibandingkan dengan pembelajaran yang konvensional. Hal tersebut juga diperkuat dengan kajian yang dilakukan oleh Yunita Julistiani (2013) mengatakan bahwa terdapat pengaruh positif dan signifikan antara gaya belajar terhadap prestasi belajar.

\section{KESIMPULAN}

Hasil penelitian yang telah dilakukan, dapat ditarik kesimpulan bahwa gaya belajar siswa yang mengacu Model Grasha-Reichmann Pada Mata Pelajaran Kelompok Kejuruan Kelas $X$ SMK Kompetensi Keahlian Teknik Gambar Bangunan dapat dilihat di bawah ini:

1. Pada Mata Pelajaran Konstruksi Bangunan, gaya belajar siswa adalah collaborative/kerjasama. Sedangkan dari hasil wawancara dengan guru pengampu, selama proses pembelajaran gaya mengajar guru adalah ceramah.

2. Pada Mata Pelajaran IImu Ukur Tanah, gaya belajar siswa collaborative/kerjasama. Sementara hasil wawancara menunjukkan gaya mengajar guru pengampu mata pelajaran adalah ceramah.

3. Hal yang sama juga ditunjukkan oleh siswa pada Mata Pelajaran Mekanika Teknik dengan gaya belajar siswa collaborative/kerjasama dan hasil wawancara dengan guru juga 
menunjukkan bahwa gaya mengajar guru tersebut adalah ceramah.

4. Sedangkan pada Mata Pelajaran Gambar Teknik, gaya belajar participant/partisipasi. Hasil wawancara juga gaya mengajar guru menggunakan metode tutor sebaya.

5. Adanya perbedaan antara gaya belajar siswa dengan gaya mengajar guru menunjukkan hasil yang diperoleh oleh setiap siswa juga memiliki perbedaan.

\section{DAFTAR PUSTAKA}

Arikunto, Suharsimi. (2010). Prosedur Penelitian Suatu Pendekatan Praktik. Jakarta: PT Rineka Cipta.

Chairunnisa, Ajeng. (2012). Hard Skill dan Soft Skill. http://ajengnissaa.blogspot.com/ 2012/03/hard-skill-dan-softskill.html [24 Juni 2015]

Danasasmita, E. Kosasih. 2009. Profil Gaya Belajar Siswa SMKN 5 Bandung Pada Pembelajaran Normatif, Adaptif, dan Produktif [skripsi]. Bandung. Universitas Pendidikan Indonesia.

DePorter, Bobbi \& Hernacki, Mike. 2000. Quantum learning: membiasakan belajar nyaman dan menyenangkan. Bandung: Kaifa.

Diaz, D. P., \& Cartnal, R. B. (1999). Students' learning styles in two classes: Online distance learning and equivalent oncampus. College Teaching 47(4), 130-135. http://www.c3l.uni- oldenburg.de/cde/support/readin gs/diaz.htm [4 Maret 2015]

Dimyati dan Mudjiono. 2002. Belajar dan Pembelajaran. Jakarta: PT. Asdi Mahasatya.

Fahrianti, Marthia. 2012. Studi Gaya Mengajar Berdasarkan Gaya Belajar Siswa Pada Materi AutoCAD [skripsi]. Jakarta: Fakultas Teknik, Universitas Negeri Jakarta.

Fahreza, Muhammad. 2014. Pengertian Konsentrasi menurut Beberapa Ahli.

https://mfahreza742.wordpress. com/2014/05/14/pengertiankonsentrasi-menurut-beberapaahli/ [15 Maret 2015]

Ghufron, M. Nur \& Risnawati, Rini. 2012. Gaya Belajar: kajian teoretik. Yogyakarta: Pustaka Pelajar.

Grasha, Tony. 1996. Teaching with Style: A Practical Guide to Enhanching Learning by Understanding Teaching and Learning Styles. San Bernadino: Alliance Publishers. http://www.Itseries.com/LTS/site pgs/GRSLSS/styles.htm [4 Maret 2015]

Gunawan, Adi W. 2003. Genius Learning Strategy, Petunjuk Praktis untuk Menerapkan Accelerated Learning. Jakarta: PT. Gramedia Pustaka Utama.

Hamalik, Oemar. 2006. Proses Belajar Mengajar. Bandung: Bumi Aksara. 
Hamidah, Jaafar Sidek. 2009. The Social Interaction Learning Style of Science and Social Science Students. Malaysia: Faculty of Applied Sciences: Universiti Teknologi MARA Perlis. www.cccsenet.org/journal.html

[4 Maret 2015]

International Journal of Social, Education, Economics and Management Engineering Vol:4, No:3, 2010.

Julistiani, Yunita. 2013. Pengaruh Gaya Belajar Terhadap Prestasi Belajar Siswa Kelas XI Kompetensi Keahlian Teknik Gambar Bangunan di SMK Negeri 5 Bandung [skripsi]. Jakarta: Universitas Pendidikan Indonesia

Margono, Drs. S. 2010. Metodologi Penelitian Pendidikan. Jakarta: PT. Rineka Cipta.

Nurman. 2006. Hubungan Gaya Belajar Terhadap Hasil Belajar Mata Pelajaran Akuntansi [skripsi]. Jakarta: Fakultas Ekonomi, Universitas Negeri Jakarta

Ngalim, Purwanto. 2009. Prinsip-prinsip dan Teknik Evaluasi Pengajaran. Bandung: Remaja Rosdakarya.

Purwanto. 2007. Metode Penelitian Kuantitatif untuk Psikologi dan Pendidikan. Yogyakarta: Pustaka Pelajar.

Purwanto. 2011. Evaluasi Hasil Belajar. Yogyakarta: Pustaka Pelajar.

Riyadi, Pawit. 2011. Partisipasi Belajar Siswa. http://pawitriyadi87.blogspot.co m/2011/12/partisipasi-belajar-

siswa.html [24 Juni 2015]

Saputera, Yohanor. 2012. Belajar Gambar Teknik. http://yohan46.blogspot.com/20 12/05/belajar-gambar-teknikyuk.html [10 Juli 2015]

Sardiman A. M,. 2005. Interaksi \& Motivasi Belajar Mengajar. Jakarta: Raja Grafindo Persada.

Siregar, Eveline \& Nara, Hartini. 2010. Teori Belajar dan Pembelajaran. Bogor: Ghalia Indonesia.

Sudjana, Dr. Nana. 2009. Penilaian Hasil Proses Belajar Mengajar. Bandung: PT. Remaja Rosdakarya.

Sugiyono, Prof. Dr. 2010. Metode Penelitian Pendidikan: Pendekatan Kuantitatif, Kualitatif , dan R\&D. Bandung: Alfabeta.

Sukmadinata, Prof. Dr. Nana Syaodih. 2010. Metode Penelitian Pendidikan. Bandung: Rosda.

Suratno. 2013. Penanaman Nilai Kerjasama Untuk Membentuk Kompetensi Mahasiswa Dalam Perspektif Pembelajaran Kolaboratif [disertasi]. Lampung: Fakultas Keguruan dan IImu Pendidikan, Universitas Lambung Mangkurat. http://www.academia.edu/41059 78/Penanaman Nilai Kerjasam a_Untuk_Membentuk_Kompete nsi Mahasisa Dalam Perspekti f_Pembelajaran_Kolaboratif $[24$ Juni 2015] 
Susilo, M. Joko. 2009. Sukses dengan Gaya Belajar. Yogyakarta: PINUS.

Sutikno, M. Sobry. 2005. Pembelajaran Efektif. Mataram: NTP Press

Ulya, Jauharatul. 2013. Keberhasilan Program Praktik Kerja Industri
Ditinjau Dari Prestasi Mata

Pelajaran Produktif dan Minat

Praktik Pada Peserta Didik Kelas XI SMK Muhamadiyah 2 Surakarta Tahun Ajaran 2012/2013 [skripsi]. Surakarta: Universitas Muhamadiyah Surakarta. 